\title{
The evolution of sputum cytometry to assess bronchitis
}

\author{
Hui Fang Lim MBBS MMed MRCPUK ${ }^{1}$, Parameswaran Nair MD PhD FRCP FRCPC ${ }^{2}$
}

A irway inflammation is not routinely assessed in the management of airway diseases such as asthma, chronic obstructive pulmonary disease or chronic cough. This is an important limitation because the pathogenesis of airway disease includes three nonoverlapping components: airway inflammation (ie, bronchitis); airflow obstruction; and hyper-responsiveness (1). Bronchitis can be measured noninvasively by sputum cell counts, the fraction of exhaled nitric oxide (FENO) and exhaled breath measurements (2). Sputum cell count quantification has been shown to have important clinical use in reducing eosinophilic asthma exacerbations $(3,4)$, guiding treatment and selecting patients for treatment with biologics (5). Athough exhaled nitric oxide can predict steroid responsiveness in patients with mild airway diseases (6), it may have less clinical applicability, particularly in patients with severe airway diseases because it may not be directly related to the degree of sputum eosinophilia (7) and, thus, may not be able to monitor disease and titrate treatment (8). Sputum cell counts can help advance our understanding of different endophenotypes and their pathobiological pathways in conditions such as asthma and chronic obstructive lung disease $(9,10)$. Compared with FENO, sputum cell counts provide information on the type (eosinophilic versus neutrophilic) and degree of airway inflammation. This will increase our understanding of various endophenotypes - especially the severe and treatment-refractory types - to help physicians predict response to novel therapies and, importantly, to allocate the appropriate treatment to the correct patient.

The technology for examining sputum has evolved in the past 20 years. In the late 1980s to early 1990s, Gibson et al (11) and Pin et al (12) demonstrated a method for obtaining sputum differential cell counts from sputum smears (self-expectorated or induced) that was reproducible and valid. However, the problem with using sputum smears was that cellular definition was poor and this made cell counting very laborious. Subsequently, this problem was overcome when sputum, separated from saliva, was treated with dithiothreitol to disperse mucus and cytospins were used to facilitate cell dispersion (13). The treated sputum is then filtered through a nylon mesh over a funnel, and the final sputum specimen is examined using an inverted microscope that selects parts that are uncontaminated by squamous cells. The cell counts obtained using this method show excellent interand intraobserver repeatability and are responsive to changes in and across disease states (14). To simplify and standardize this process, a novel processing device (Accufilter, Cellometrics Inc, Canada) has been developed (15). The simplified technology can reduce the workload in centres with large sample loads.

Establishing normal values is a prerequisite for the introduction of a biomarker into clinical practice. Three previous studies have attempted to describe the reference ranges of sputum cell counts in normal individuals (16-18). In the current issue of the Journal, Davidson et al (19) (pages 424-428) show that the current reference values based on the original study by Belda et al (16) are equally applicable in western Canada and at elevated altitude. Appropriate statistical methods were used, although the sample size was not justified and the lower sample size compared with previous studies may have contributed to the slightly higher variability in cell counts observed in this study. A 'normal' reference range may vary according to demographic factors, comorbidities and exposure to environmental influences such as pollution and smoking. The study by Belda et al (16) reported a higher total and absolute neutrophil cell count compared with the other studies. It was conducted in Hamilton (Ontario) and may have been skewed by the ambient pollution of an industrialized city and by prevailing climatic conditions that may affect the neutrophil and macrophage counts (20). They also reported increased sputum eosinophilia with atopy and female sex. The study by Thomas et al (18) found that the sputum neutrophil differential counts increased significantly with age. Yet, it is reassuring that the central measures and variances reported from these centres from three different continents are remarkably similar.

Currently, there are several limitations in the routine sputum processing methods in practice: first, sputum specimens must be examined within $2 \mathrm{~h}$; second, as described above, it requires multiple steps; and third, it requires a certified technologist trained in the examination of cell counts for it to be standardized, reliable and real time. Refrigeration at $4^{\circ} \mathrm{C}$ can preserve cell morphology and accuracy of cell counts for up to $9 \mathrm{~h}$ (21). Sputum fixation or preservation of sputum may extend the time between collection and processing by allowing sputum examination to be delayed for up to $72 \mathrm{~h}(22,23)$, thus facilitating transport to a dedicated laboratory for subsequent examination. Sputum can be preserved in $10 \%$ buffered formalin or $2 \%$ paraformaldehydedithiothreitol fixative. The preservatives may increase cellular counts by rapidly inactivating cellular enzymes and by stabilizing cell membranes, thus resulting in increased cell recovery. However, the effect of preservation on total expectorate compared with saliva-free expectorate may be different and this may affect the interobserver repeatability of cell differentials (24). Thus, it is important to note that the normal reference range using the preservation methods described in the article by Davidson et al (19) may be slightly different from the methods that examine freshly expectorated sputum; however, the differences may not be clinically relevant. This method may help to promote widespread use of sputum analysis in clinical practice and research, and remove one barrier from its implementation in the routine care of patients with airway diseases. In the future, development of a point-ofcare biomarker for bronchitis would further enhance its widespread adoption and clinical application (25).

DISCLOSURE: Dr Nair is supported by a Canada Research Chair in Airway Inflammometry.

\section{REFERENCES}

1 Rosi E, Ronchi MC, Grazzini M, et al. Sputum analysis, bronchial hyperresponsiveness, and airway function in asthma: Results of a factor analysis. J Allergy Clin Immunol 1999;103:232-7.

2 Nair P, Hargreave FE. Measuring bronchitis in airway diseases: Clinical implementation and application: Airway

hyperresponsiveness in asthma: Its measurement and clinical significance. Chest 2010;138:38S-43S.

${ }^{1}$ Division of Respiratory $\mathcal{E}$ Critical Care Medicine, National University Hospital, Singapore; ${ }^{2}$ Firestone Institute for Respiratory Health, St Joseph's Healthcare $\mathcal{E}^{3}$ McMaster University, Hamilton, Ontario

Correspondence: Dr Parameswaran Nair, Firestone Institute for Respiratory Health, St Joseph's Healthcare Hamilton, 50 Charlton Avenue East,

Hamilton, Ontario L8N 4A6. Telephone 905-522-1155 ext 35044, fax 905-521-6183, e-mail parames@mcmaster.ca 
3. Jayaram L, Pizzichini MM, Cook RJ, et al. Determining asthma treatment by monitoring sputum cell counts: Effect on exacerbations. Eur Respir J 2006;27:483-94.

4. Green RH, Brightling CE, McKenna S, et al. Asthma exacerbations and sputum eosinophil counts: A randomised controlled trial. Lancet 2002;360:1715-21.

5. Nair P, Pizzichini MM, Kjarsgaard M, et al. Mepolizumab for prednisone-dependent asthma with sputum eosinophilia. N Engl J Med 2009;360:985-93.

6. Barnes PJ, Dweik RA, Gelb AF, et al. Exhaled nitric oxide in pulmonary diseases: A comprehensive review. Chest 2010;138:682-92.

7. Nair P, Kjarsgaard M, Armstrong S, et al. Nitric oxide in exhaled breath is poorly correlated to sputum eosinophils in patients with prednisone-dependent asthma. J Allergy Clin Immunol 2010;126:404-6.

8. Petsky HL, Cates CJ, Lasserson TJ, et al. A systematic review and meta-analysis: Tailoring asthma treatment on eosinophilic markers (exhaled nitric oxide or sputum eosinophils). Thorax 2012;67:199-208.

9. Auffray C, Adcock IM, Chung KF, et al. An integrative systems biology approach to understanding pulmonary diseases. Chest 2010;137:1410-6.

10. Lotvall J, Akdis CA, Bacharier LB, et al. Asthma endotypes: A new approach to classification of disease entities within the asthma syndrome. J Allergy Clin Immunol 2011;127:355-60.

11. Gibson PG, Girgis-Gabardo A, Morris MM, et al. Cellular characteristics of sputum from patients with asthma and chronic bronchitis. Thorax 1989;44:693-9.

12. Pin I, Gibson PG, Kolendowicz R, et al. Use of induced sputum cell counts to investigate airway inflammation in asthma. Thorax 1992;47:25-9.

13. Popov T, Gottschalk R, Kolendowicz R, et al. The evaluation of a cell dispersion method of sputum examination. Clin Exp Allergy 1994;24:778-83.
14. Pizzichini E, Pizzichini MM, Efthimiadis A, et al. Indices of airway inflammation in induced sputum: Reproducibility and validity of cell and fluid-phase measurements. Am J Respir Crit Care Med 1996;154:308-17.

15. Chaboillez S, Dasgupta A, Prince P, et al. A kit to facilitate and standardize the processing of sputum for measurement of airway inflammation. Can Respir J 2013;20:248-52.

16. Belda J, Leigh R, Parameswaran K, et al. Induced sputum cell counts in healthy adults. Am J Respir Crit Care Med 2000;161:475-8.

17. Spanevello A, Confalonieri M, Sulotto F, et al. Induced sputum cellularity. Am J Respir Crit Care Med 2000;162:1172-4.

18. Thomas RA, Green RH, Brightling CE, et al. The influence of age on induced sputum differential cell counts in normal subjects. Chest 2004;126:1811-4.

19. Davidson WJ, The S, Leigh R. Establishing a normal range for induced sputum counts in Western Canada. Can Respir J 2013;20:424-8.

20. Wallace J, Nair P, Kanaroglou P. Atmospheric remote sensing to detect effects of temperature inversions on sputum cell counts in airway diseases. Environ Res 2010;110:624-32.

21. Efthimiadis A, Jayaram L, Weston S, Carruthers S, Hargreave FE. Induced sputum: Time from expectoration to processing. Eur Respir J 2002;19:706-8.

22. Kelly MM, Hargreave FE, Cox G. A method to preserve sputum for delayed examination. Eur Respir J 2003;22:996-1000.

23. Hasan SA, Traves SL, Leigh R, Kelly MM. A method to allow preservation and delayed examination of induced unselected sputum. Am J Respir Crit Care Med 2010;181:A4276.

24. Pizzichini E, Pizzichini MM, Efthimiadis A, Hargreave FE, Dolovich J. Measurement of inflammatory indices in induced sputum: Effects of selection of sputum to minimize salivary contamination. Eur Respir J 1996;9:1174-80.

25. Wheelock CE, Goss VM, Balgoma D, et al. Application of 'omics technologies to biomarker discovery in inflammatory lung diseases. Eur Respir J 2013;42:802-25. 


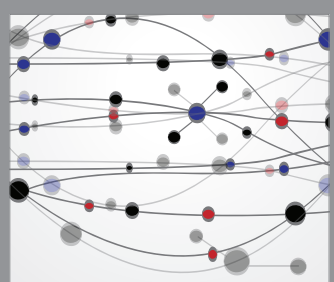

The Scientific World Journal
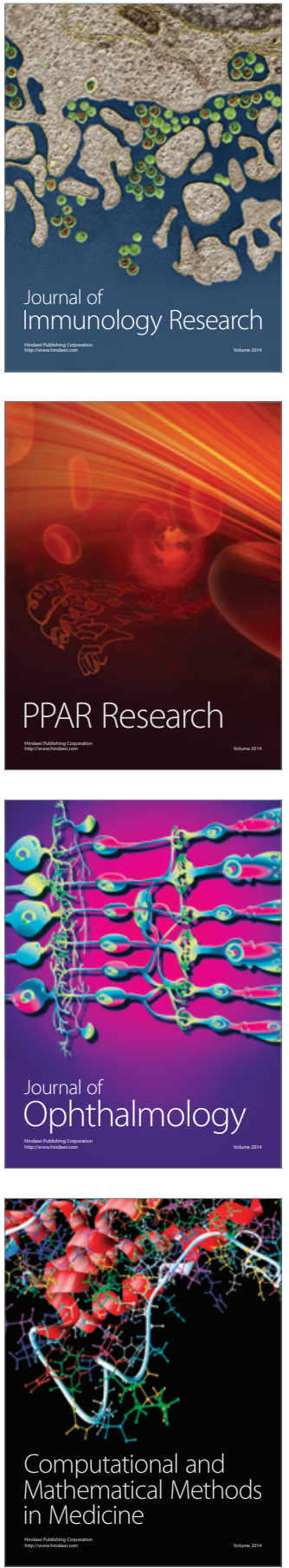

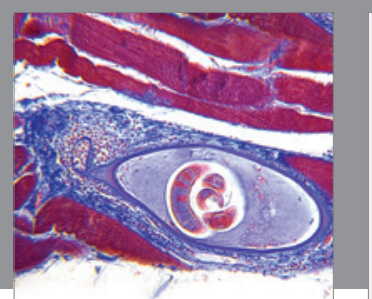

Gastroenterology Research and Practice

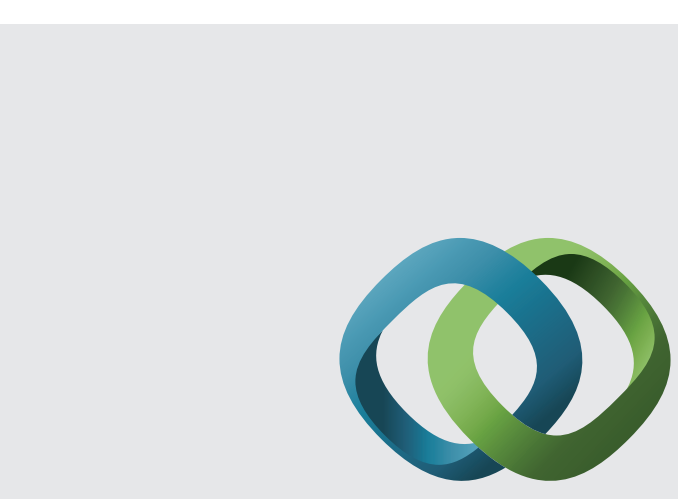

\section{Hindawi}

Submit your manuscripts at

http://www.hindawi.com

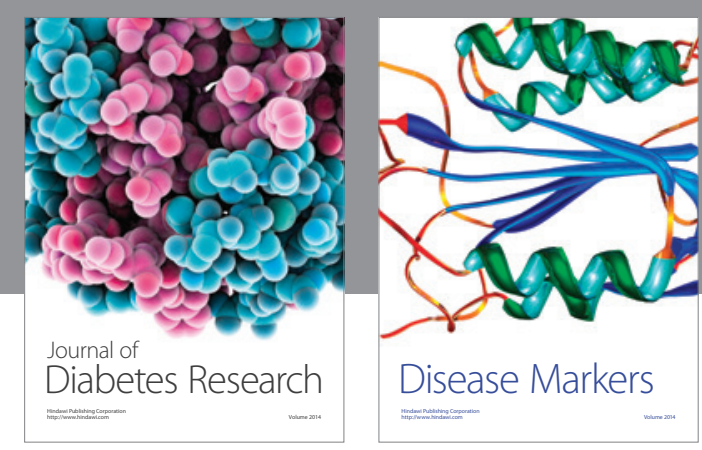

Disease Markers
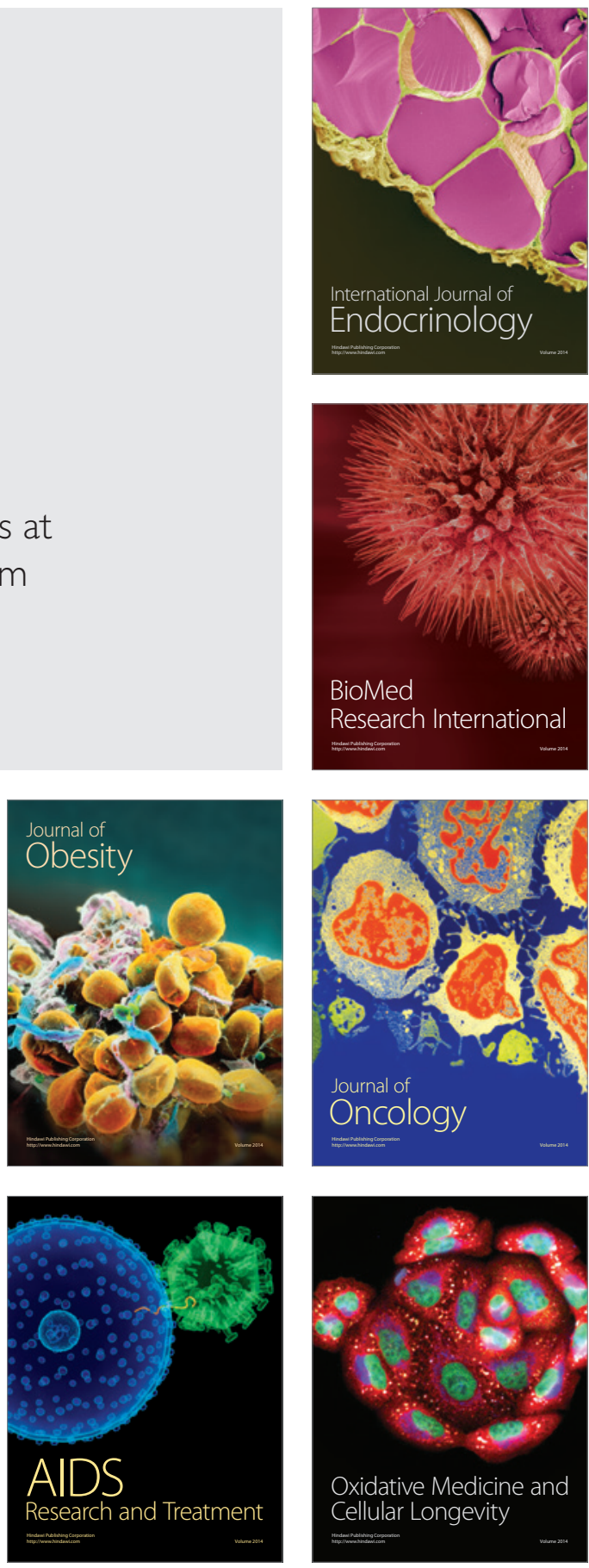